Медникова Анна Анатольевна

аспирантка кафедры теории права и правоохранительной деятельности Санкт-Петербургского гуманитарного университета профсоюзов преподаватель Санкт-Петербургского технического колледжа управления и коммерции

\section{АНАЛИЗ ПРОБЛЕМАТИКИ ИНСТИТУТА ПРИЗНАНИЯ ГОСУДАРСТВ}

\section{Аннотация}

Статья посвящена феномену непризнанных государств и ключевым понятиям в области признания государств. Описываются проблемы признания кратко анализируются применимые в прошлом инструменты признания независимости, прослеживается эволюция института признания государства. Анализ состояния современных механизмов признания позволил оценить современные и перспективные тенденции решения проблем в данной области. Феномен непризнанного государства соcтоит в расхождении юридического механизма и фактической реализации права признания. В настоящее время феномен непризнанных государств заmрагивает в большей степени политические ас пекты, так как само понятие «признание» является условным в силу отсутствия четкой регламентации института признания и наличия юридических коллизий. Признание является правом при знающего государства, выражающим его готовность поддерживать международные, дипломатические, консульские и другие отношения, а не обязанностью признающего государства, что обусловливает необходимость конкретной кодификации и модернизации механизмов признания.

\section{Ключевые слова:}

непризнанное государство, признание, внешний суверенитет, внутренний суверенитет, сецессия, право на самоопределение, юридическая техника признания государства.
Mednikova Anna Anatolyevna

PhD student,

Law Theory and Law Enforcment Department, St. Petersburg University of Humanities and Social Sciences, Lecturer, St. Petersburg Technical College of Management and Commerce

\section{THE PROBLEMATIC ANALYSIS OF THE INSTITUTION OF STATE RECOGNITION}

Summary

The research covers the phenomenon of unrecognized states and the key concepts concerning the recognition of states. The problems of recognition are described; the prior protocols for granting sovereignty are briefly analyzed; the evolution of the institution of state recognition is traced. The paper analyzes the modern mechanisms of state recognition, assesses the current and prospective trends towards addressing the issues in this regard. The phenomenon of an unrecognized state is the difference in the legal mechanism and the implementation of the right of recognition in fact. The current phenomenon of unrecognized states increasingly affects the political aspects, since the concept of recognition is contextual due to the lack of clear regulation of this institution and legal conflicts. Recognition is the right of the recognizing state that demonstrates its readiness to support international, diplomatic, consular and other relations rather than the responsibility of the recognizing state and hence requires the specific codification and modernization of the mechanisms of recognition.

Keywords:

unrecognized state, recognition, external sovereignty, internal sovereignty, sovereignty, secession, right to self-determination, legal protocols of state recognition.

Институт признания государств не только является древнейшим институтом в системе международных отношений, но также выступает ключевым актом, который оказывает влияние на становление и развитие государства в целом. Признание со стороны мирового сообщества влияет на жизнь населения на правовом и нормативном уровне, а также оказывает колоссальное воздействие на людей, проживающих в государстве, определяет уровень его экономического развития и регулирует вопросы, связанные с миграцией.

Непризнанное государство обычно возникает с момента одностороннего отделения части территории и выхода отколовшейся территории из-под контроля государственной власти. Сецессия (лат. secessio - 'уход', от secedo - ‘ухожу') - выход из состава государства. Причины сецессии могут быть различными, но обычно это угроза государственному строю или борьба за новые условия, отторжение другой культуры, подавление со стороны властей или желание преобразования государственной власти и др. Сам механизм сецессии может быть вызван различными причинами. Данный акт носит неоднозначный и спорный характер, так же как и сам институт признания. Каждый случай и история каждого государства уникальны, что обусловлено не только историческими, но также и причинно-следственными обстоятельствами. Также существует ряд стран несецессионистского происхождения. Не всегда конечной целью конфликтной территории является образование нового государства. Многие непризнанные государства в прошлом стремились отсоединиться от одного государства и присоединиться к новому, которое, с их точки зрения, отвечает их позициям, например ближе по национальной принадлежности или способно создать положительные условия для правового роста и развития. 
В научных трудах вопрос непризнанных государств рассматривается с исторической, политической, правовой, географической точек зрения, приводится классификация спорных территорий, выявляются проблемы указанного феномена [1]. По мнению многих авторов, понятие «непризнанное государство» условно. К категории непризнанных государств, как правило, относят и частично признанные государства, однако поле деятельности и компетенции частично признанных государств ограничены правовой зоной признавших их суверенитет государств. Главным критерием для отнесения к той или иной группе является возможность контроля над своей территорией, а также наличие хотя бы незначительного признания со стороны других государств [2, с. 133].

Ниже представлен список непризнанных и частично признанных государств по данным на 2018 г. Приведен ограниченный список, без квазигосударств, так как данная категория лишена нужного комплекта признаков государственности: Азад Джамму и Кашмир, год провозглашения независимости - 1948 г., Донецкая Народная Республика - 2014 г., Китайская Республика 1911 г., Луганская Народная Республика - 2014 г., Нагорно-Карабахская Республика - 1991 г., Приднестровская Молдавская Республика - 1990 г., Республика Абхазия - 1994 г., Республика Косово - 2008 г., Республика Южная Осетия - 1991 г., Сахарская Арабская Демократическая Республика - 1976 г., Сомалиленд - 1991 г., Турецкая Республика Северного Кипра - 1983 г.

Также существует ряд государств, пытающихся установить свой суверенитет силовым методом. Другие страны относят их к сепаратистским и оккупированным территориям.

Можно ли считать Шотландию непризнанным государством? В силу сложившихся исторических причин Шотландия была завоевана и в настоящий момент входит в состав Великобритании, но желание вернуть себе независимость ярко проявляется до сих пор. Такой же вопрос возникает с ситуацией Испании и Каталонии, не считая множества других примеров. В статье список непризнанных и частично признанных государств был определен наличием признаков государственности.

Феномен непризнанного государства состоит в расхождении юридического механизма и фактической реализации данного права признания. По фракту существует сложившееся исторически и сумевшее отстоять свои позиции государство, провозгласившее себя суверенным, а также обладающее всеми признаками государственности, такими как наличие территории и правительства, официального названия, государственной символики, границ и территориального контроля, собственного населения с конституционными правами и обязанностями, внутреннего суверенитета и др. Вместе с тем юридически наблюдаются полное или частичное игнорирование со стороны мирового сообщества, отсутствие внешнего суверенитета и дипломатического признания.

Статус - понятие непостоянное: можно получить фактическую независимость, но дальнейшая дипломатическая судьба государства зависит от мнения так называемого клуба уже признанных государств.

В источниках права нет четкого понятия института признания и не обозначена точная регламентация данного процесса, однако практика устанавливает разный объем признания государств. Исходя из этого, существуют следующие фрормы признания: юридическая и фрактическая.

Международно-правовое признание подкрепляется актом признающего государства, выражающего свою готовность вступить в юридические отношения с иным субъектом международных отношений. Таким образом, признание является правом признающего государства, выражающим его готовность поддерживать международные отношения, но не являющимся обязанностью для государства.

Возникает закономерный вопрос: с какого момента можно считать государство независимым - с момента фрактического существования и самого провозглашения или с момента признания со стороны международного сообщества? Если с момента признания другими странами, то какое количество стран должно согласиться с возникновением нового государства и какие критерии определяют уровень самостоятельности государства?

В литературе можно встретить различные критерии для международного признания непризнанных государств, однако все эти критерии определены условно. Попытки сформулировать четкие критерии для осуществления процедуры признания были предприняты 16 декабря 1991 г. при признании государств, сформировавшихся на территории бывшего советского пространства и бывшей Югославии. Европейское сообщество в Брюсселе подписало «Принципы признания новых государств в Восточной Европе и в Советском Союзе». В данном документе мировое сообщество выразило готовность признания независимости каждого отдельного случая в соответствии с международными принципами, практикой и политическими задачами. В основе данного заявления лежали принципы Хельсинкского заключительного акта и Парижской хартии, в особенности право на самоопределение.

Рассмотрим один из ключевых принципов международного права: «Все народы имеют право на самоопределение. В силу этого права они свободно устанавливают свой политический статус и свободно обеспечивают свое экономическое, социальное и культурное развитие» [3]. 
Таким образом, возникает еще один закономерный вопрос: почему нарушается один из общеизвестных принципов международного права - право на самоопределение?

Наблюдается ярко выраженное противоречие, так как не стоит забывать о еще одном основополагающем принципе - нерушимости границ, что приводит к столкновению двух малосовместимых на практике техник.

Таким образом, первоочередная проблема в данной области исследования - отсутствие четкой регламентации процедуры признания. Нормы международного права в области признания государств являются некодифрицированными. Юридическую основу в сфрере признания государств составляют международные обычаи, принципы международного права и акты международных организаций. По фракту решающую роль в вопросах признания играют опыт и разнообразная практика государств и международных организаций.

Далее раскроем, что такое институт признания государства, и проследим его эволюцию.

Если обратиться к истории, институт признания непрерывно связан с естественным путем возникновения самого государства. В прошлом институт признания также являлся некодифицированным институтом, опирался на традиции, доктрины и общие принципы норм права.

Понятие государственного суверенитета было закреплено в XVI в. фрранцузским юристом Жаном Боденом, который дал следующее определение государственного суверенитета: «Суверенитет - это абсолютная и постоянная власть государства... Абсолютная, не связанная никакими законами власть над гражданами и подданными» [4, с. 172]. Таким образом, Ж. Боден определил суверенитет как полную безграничную власть государства, свободу от власти папы римского, от церкви и от других государств. По его мнению, суверенитет - это безграничное верховенство власти монарха в государстве, полученное им по праву рождения, в силу естественных причин. Монарх есть само государство, это голос, судья и палач народа, его воля первична и абсолютна.

Таким образом, признание государства начинается с наличия суверенитета. Отсутствие национального суверенитета, как следствие, и самого фракта признания - признак слабости государства и его неспособности отстаивать внутренние, внешние и национальные интересы. Для процветания государства, развития экономики и улучшения жизни населения необходим акт признания со стороны других государств, что поможет государству стать полноценным субъектом международной арены.

Именно практика и традиции закрепляли функционирование института признания в прошлом. Например, если говорить о Руси, наличие царского титула давало возможность занять сильные позиции в дипломатических отношениях между государствами. Титул «царь» имел не только юридическое значение, он служил инструментом, позволяющим добиться уважения, а следовательно, и признания со стороны других государств. Данный статус имел материальное значение, закреплял перечень территорий, на которые распространяется власть царя, а количество территорий, в свою очередь, закрепляло авторитет и говорило о силе и экономическом благополучии государства [5].

Царский титул для русских правителей имел такое же значение, что и императорский титул, однако история говорит об обратном: не все европейские государства были согласны с этим. В данном случае уже начинали функционировать другие механизмы, позволяющие укрепить позиции признания, например заключение династических браков (имело прямое отношение к укреплению позиций в области интернационального признания), заключение выгодных международных договоров, религиозная преемственность, так как общность религиозных убеждений, кровное родство и наличие выгоды - гарант долгого мирного сотрудничества и межгосударственного признания.

Еще один яркий пример - признание государственности папы римского. В данном случае задействованы более тонкие механизмы, не привязанные к территории, проявляющиеся в применении религиозных рычагов. Как видно из исторических событий, признание власти папского государства распространялось далеко за пределы Ватикана, т. е. его власть и статус носили общепризнанный международный характер. Таким образом, в прошлом институт признания также являлся некодифицированным, он опирался на практику, традиции и доктрины и применял методы мирного дипломатического сотрудничества.

В современном мире силовой метод отделения территории не позволяет решить вопросы установления независимости государства и достижения признания. Глобализация интеграционных процессов усложняет процесс разрешения вопроса признания мирным путем в силу наличия постороннего вмешательства [6]. Как правило, что было невозможно раньше в связи с географиическими причинами, в настоящий момент возможно, так как границы между государствами сближаются с точки зрения информационного аспекта. Свое мнение по поводу принадлежности той или иной территории к стране или возможности признания высказывают страны, территориально находящиеся на другой части света. Таким образом, ведущие страны мира способны регулировать вопросы признания на политическом уровне и оказывать отдаленное влияние. 
Как показывает практика и подчеркивают зарубежные исследователи Ц. Рингарт и С. Собре, основополагающую роль в акте признания в настоящее время играет политический аспект, а не юридический, правовые нормы носят вторичный характер, что сопровождает процесс признания наличием конфликтных ситуаций, перерастающих в вооруженное противостояние [7, р. 467]. Необходимо обновление нормативной основы для признания, которая объединит как фрактические, так и моральные критерии.

Вышеприведенная информация с учетом геополитического контекста демонстрирует ясную картину того, что непризнанные государства становятся своеобразными заложниками конкуренции между ведущими мировыми игроками [8, с. 345-347].

Отсутствие объективного института признания государства отрицательно влияет на интегрирующие процессы в вопросах международного содействия. Прослеживается негативный аспект политических и правовых последствий нездорового стрессового функционирования непризнанных государств, что обусловлено медленным ростом экономики и заторможенностью операционных возможностей непризнанных государств, не говоря уже о низком правовом статусе, вооруженных конфликтах и низком уровне жизни людей, получающих гражданство несуществующего государства. Паспорта жителей несуществующих государств, как правило, не имеют юридической силы и не позволяют посещать территории других стран, граждане получают не имеющие юридической силы аттестаты и дипломы не существующих на правовом уровне учебных заведений, жизнь населения представляет собой вакуум, обусловливающий низкий уровень развития экономики и рост эмиграции [9].

Для улучшения регулирования вопросов, связанных с институтом признания, предложим несколько направлений, обращенных к разрешению проблем в области признания, систематизация и научная обоснованность которых могут послужить их дальнейшему практическому применению:

- кодификация института признания, обобщающая международную практику в области признания, которая позволит упразднить юридические коллизии в данном вопросе и сформировать последовательную юридическую технику признания, определить список критериев государственности, необходимых для акта признания;

- совершенствование внутригосударственной политики в вопросах практической реализации правовых норм института признания и сотрудничества государств в области соблюдения мира и безопасности;

- возведение акта признания со стороны признающих государств до правоустанавливающего обстоятельства обязанности и сведение к минимуму политического значения международного признания.

Статья является попыткой анализа противоречивого феномена фрактического существования и юридического отсутствия непризнанных государств на карте мира. Ситуация с признанием стоит крайне остро, нет четкой регламентации процедуры признания. Современные непризнанные государства в силу естественных глобализационных процессов не могут пройти долгий путь становления внешнего суверенитета и достижения статуса независимого государства, применяемый государствами в прошлом, не только опирающийся на фрактический откол территории, но и затрагивающий другие механизмы признания, такие как сроки давности, дипломатическое союзничество, экономические договоры, а также, безусловно, уважение статуса и титула, так как сегодня задействованы иные, преимущественно политические и глобальные механизмы.

\section{Ссылки:}

1. Николаев Д.Г. Феномен непризнанных государств в мировой политике // Вестник Московского университета. Серия 25. Международные отношения и мировая политика. 2010. № 1. С. 27-41.

2. Жмилевский В.Д. Непризнанные и частично признанные государства: географические аспекты исследований // Молодой ученый. 2016. № 30 (134). С. 133-136.

3. Об экономических, социальных и культурных правах : междунар. пакт от 16 дек. 1966 г. : принят Резолюцией $2200(X X I)$ на 1496-м пленарном заседании Генеральной Ассамблеи ООН // Бюллетень Верховного суда Российской Федерации. 1994. № 12. Ст. 1 ; О гражданских и политических правах : междунар. пакт от 16 дек. 1966 г. : принят Резолюцией 2200 (XXI) на 1496-м пленарном заседании Генеральной Ассамблеи ООН // Ведомости Верховного Совета СССР. 1976. № 17. Ст. 1.

4. Нерсесянц В.С. История политических и правовых учений : учеб. для вузов. М., 2014. 704 с.

5. Цвицинская Н. Эволюция института признания государства в международном праве // История и современность. 2014. № 2 (20). С. 147-161.

6. Лукашук И.И. Глобализация, государство, право, XXI век. М., 2000. 262 с.

7. Ryngaert C., Sobrie S. Recognition of States: International Law or Realpolitik? The Practice of Recognition in the Wake of Kosovo, South Ossetia and Abkhazia // Leiden Journal of International Law. 2011. Vol. 24, iss. 2. P. 467-490.

8. Бабурин С.Н. Территория государства. Правовые и геополитические проблемы. М., 1997.480 с.

9. Тишков В. Социально-культурная природа терроризма [Электронный ресурс] // Неприкосновенный запас. 2002. № 6 (26). URL: http://magazines.russ.ru/nz/2002/6/tish.html (дата обращения: 11.07.2018). 


\section{References:}

'2200 (XXI). International Covenant on Civil and Political Rights adopted by the General Assembly at the1496th plenary meeting on December 16, 1966' 1976, Vedomosti Verkhovnogo Soveta SSSR, no. 17. Art. 1, (in Russian).

'2200 (XXI). International Covenant on Economic, Social and Cultural Rights adopted by the General Assembly at the1496th plenary meeting on December 16, 1966' 1994, Byulleten' Verkhovnogo suda Rossiyskoy Federatsii, no. 12. Art. 1, (in Russian).

Baburin, SN 1997, Territory of the state. Legal and geopolitical problems, Moscow, 480 p., (in Russian).

Lukashuk, II 2000, Globalization, state, law, the 21st century, Moscow, 262 p., (in Russian).

Nersesyants, VS 2014, History of political and legal studies, manual, Moscow, 704 p., (in Russian).

Nikolaev, DG 2010, 'The phenomenon of unrecognized states in world politics', Vestnik Moskovskogo universiteta, Series 25, no. 1, pp. 27-41, (in Russian).

Ryngaert, C \& Sobrie, S 2011, 'Recognition of States: International Law or Realpolitik? The Practice of Recognition in the Wake of Kosovo, South Ossetia and Abkhazia', Leiden Journal of International Law, vol. 24, iss. 2, pp. 467-490. https://doi.org/10.1017/s0922156511000100

Tishkov, V 2002, 'Social and cultural nature of terrorism', Neprikosnovennyy zapas, no. 6 (26), viewed 11 July 2018, $<$ http://magazines.russ.ru/nz/2002/6/tish.html>, (in Russian).

Tsvitsinskaya, N 2014, 'Evolution of the institution of recognition of the state in international law', Istoriya i sovremennost', no. 2 (20), pp. 147-161, (in Russian).

Zhmilevsky, VD 2016, 'Unrecognized and partially recognized states: geographical aspects of research', Molodoy uchenyy, no. 30 (134), pp. 133-136, (in Russian). 